\title{
Contradictory US trade policy opens supercomputer market to Japanese
}

Washington. Agreements between the United States and Japan to protect free markets for US supercomputer manufacturers are so tangled that even US officials have apparently misread them. A dispute between US agencies allowed Japanese companies to compete for two sensitive government contracts last year despite the protests of US supercomputer companies.

John Rollwagen, chairman of Cray Research Inc., told a US congressional committee earlier this month that the National Aeronautics and Space Administration (NASA) wrongly opened a supercomputer contract to Japanese companies after deciding that a 1990 agreement requires recipro$\mathrm{cal}$ open competition. In fact, he pointed out, the 1990 agreement is a one-way street: Japan must set a fair price for any supercomputer it wants to buy and must also take into account performance, but the United States is under no such obligation.

US supercomputer makers are unhappy that the Japanese are allowed to seek US government contracts when US companies have been essentially locked out of the Japanese market. The relationship between supercomputer makers and US government researchers is also a sensitive point. Cray, with the support of US government laboratories, created the supercomputer industry. Now Cray officials are concerned that their one clear advantage over their Japanese competitors - software - may disappear if Japanese companies get help in developing software from those same laboratories.

They complain that Japanese companies have attempted to 'dump' supercomputers on the US market at implausibly low prices - even offering to donate supercomputers to the Massachusetts Institute of Tech-

\section{Selling supercomputers in Japan \\ Public sector purchases}

before and after 1987 and 1990 treaties

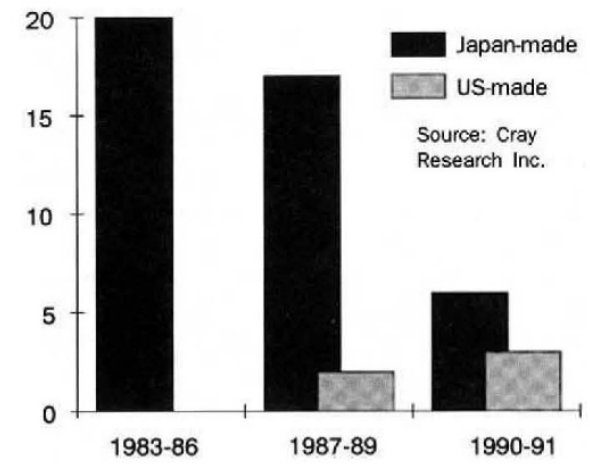

nology and a climate modelling consortium in Colorado - to gain a share of the US government and academic market. Meanwhile, Japanese companies and government laboratories have prepared specifications that require either an artificially low price or performance tailored to the strengths of Japanese machines.

In response to these complaints, the US Trade Representative (USTR) has negotiated two agreements with Japan to open the

\section{Cray claims foul play in Japan}

Tokyo. Days after John Rollwagen, chairman of Cray Research Inc., appeared before the US Congress (see above), his company complained that Japan's new National Institute for Fusion Science had given unfair advantage to the Japanese manufacturer NEC in its search for a supercomputer.

The protest, filed with the prime minister's office, is the first complaint to be made under a 1990 US-Japan agreement intended to give US manufacturers better access to Japan's government research laboratories. Cray's action will delay installation of a supercomputer at the fusion institute for at least three months while a committee investigates the claim. The institute is building the world's largest helical fusion device and needs a supercomputer to analyse the data (Nature 356,$468 ; 1992$ ).

In a press statement in Tokyo last week, Rollwagen complained that the institute's selection of NEC's SX-3 supercomputer over a Cray C90 used "odd and inconsistent measurements". He pointed out that Cray recently won a bid against the same NEC system in a contract with the US Environmental Protection Agency with a much less powerful Cray (a Y-MP system) than offered to the national fusion institute.

Atsuo liyoshi, director of the institute, says that the institute requires a computer with a system that can transfer huge amounts of data to external memory, a feature that favours NEC. But Rollwagen says that NEC's claims for its external optical storage device are exaggerated, and that there were other aspects of how the bids were scored that gave an unfair advantage to NEC. D.S.

Japanese market to US supercomputers. The first, in 1987, was generally ineffective, despite an attempt by the Japanese government to ease tensions by hurriedly buying three US machines. The 1990 agreement is considered better, but since then US companies have won only three of nine Japanese public-sector bids, despite the generally accepted technical superiority of US machines.

Given these problems, US companies were infuriated when NASA announced an open competition for new supercomputers at its Marshall Space Flight Center and Ames Research Center. In both cases, NASA had first intended to close the competitions to all but US manufacturers on the grounds of economic security.

In the case of Marshall, however, NASA was advised by another US agency that such an exemption would probably run counter to the General Agreements on Tariffs and Trade (GATT), the set of international fair trading treaties. In the Ames case, involving a more advanced supercomputer for aerodynamic simulation, NASA was able to get permission from the USTR to close the competition to non-US companies, leading a US subsidiary of the Japanese company NEC to file a formal protest. Neither competition has been concluded.

Representative John Conyers (Democrat, Michigan), chairman of the legislative and national security subcommittee of the House Government Operations Committee that held the hearings, believes that NASA was dissuaded from restricting competition by the USTR, which he says "is intent on protecting the rights of Japanese firms". Conyers says that the USTR's stance is a tactic to coax Japan to open its own markets.

Gary Edson, the USTR general counsel, denies that charge, explaining that his office had not been asked to give advice on the Marshall purchase and had approved a restricted competition for the Ames supercomputer. In his opinion, NASA decided to open the Ames competition because it was reluctant to get involved in litigation.

USTR officials say that they accept exemptions to GATT and other treaties for reasons of defence-orientated national security. But in cases where the issue is economic security, the USTR is reluctant to interfere with free trade. "Basically, we don't want our trading partners coming back and doing it to us", explains one official.

Despite protests by US companies, the Bush administration apparently takes US supercomputer makers at their word: if their machines are really better, they should be able to retain dominance of the US government market.

Christopher Anderson 